doi: https://doi.org/10.15407/microbiolj83.02.093

\title{
CONTRIBUTION OF UKRAINIAN SCIENTISTS INTO THE FIGHT AGAINST PLAGUE
}

\author{
V.M. Gamaliia, S.P. Ruda, G.V.Zabuga \\ State Institution "G.M. Dobrov Institute for Scientific and Technological \\ Potential and Science History Studies, NAS of Ukraine", \\ 60 T. Shevchenko Blvd., Kyiv, 01032,Ukraine \\ vgamaliia@gmail.com
}

\begin{abstract}
A review about history of the fighting of Ukrainian scientists against one of the most terrible infectious diseases of mankind is proposed. It is noted that plague epidemics have persecuted mankind during many centuries. For a long time, pandemics of the so-called "black death" broke out in different parts of the world. It is shown how a number of measures were organized in Russian Empire against disease spread: the organization of border outposts, the establishment of quarantine hospitals etc. Ways of searching for the sources of the plague by a number of scientists, in particular, graduates of the Kiev-Mohyla Academy, doctors I.A. Poletika, D.S. Samoylovich, K.I. Yagelsky, A.F. Shafonsky are described. The formation of the anti-plague system in Russian Empire is investigated. The activity of the anti-plague laboratory, organized on the initiative of D.K. Zabolotny in 1880 in St. Petersburg, is shown. The contribution of the doctors G.M. Minkh, V.K. Vysokovich and M.F. Gamaliia in revealing the features of the pathogenesis of plague is described. It is noted that only at the beginning of the $20^{\text {th }}$ century laboratories headed by D.K. Zabolotny and I.I. Mechnikov received significant results regarding the distribution of this dangerous infection. It is proved that only the dedicated work of a number of scientists allowed not only to reduce, but also to overcome the sickness rate of plague. It is noted that the first objective confirmation of the fact that the causative agent of the plague can be transmitted from rodents to humans was obtained in 1912. Considerable attention was paid to studies of the plague infection by D.K. Zabolotny during his expeditions to countries where epidemics arose. The role of Ukrainian scientists in establishing the determining factors of the occurrence of plague, as well as the development of methods for preventing this infectious disease, is emphasized.
\end{abstract}

Keywords: plague, vaccination, epidemiology, anti-plague serum, epizootic, endemicity.

September 2, 2020 was marked as 250 years since the plague broke out on the streets of Kyiv. The same thing had happened also before, but it was the first time when cruel disease met with adequate resistance, organized according to all the requirements of contemporary medicine.

Considering the plague the most dangerous among all the terrible diseases, I.I. Mechnikov noted: "Among all diseases, the plague has left the deepest traces in history" [1]. Information about it can be found in written memos of various peoples, starting from the VI century BC. In Europe, it was first observed in $431 \mathrm{BC}$, during the Peloponnesian War in Athens, where it was called "Thucydides plague" [2]. The next formidable epidemic was the "Antonin plague" or "Galen plague" in the Roman Empire (165 AD). But the most terrible of those ancient times is considered "Justinian plague", brought from Egypt in 541, which devastated all the countries of the Mediterranean and was called the first pandemic. The second pandemic called the "Black Death", swept through Europe since the XIV century and was lasting the next few centuries. Her invasion in Florence in 1348 was vividly reflected in Giovanni Boccaccio's Decameron [3]. In England, plague epidemics broke out repeatedly: in 1483, 1506, 1518, 1529 and 1665. The last of these, called the "Great Plague", is described in the "Diary of the Plague Year" by Daniel Defoe, author of the famous novel "Robinson Crusoe" [4].

The plague was brought to Russia from Western Europe. It reached Pskov and Novgorod through trade relations in the XIV century and spread further throughout Russia, as reported by the Novgorod Chronicle [5]. The "black death" did not bypass Ukraine too. In 1653, according to the Chernihiv 
Chronicle, "there was a great plague all over Ukraine, a lot of people died" [6]. For three years, 1661-1664, the plague raged in Ukraine again. In 1673, the population of Lviv and Zaporizhzhia especially suffered from the plague epidemic [7]. In the XVIII century 15 plague epidemics were registered in Ukraine. The epidemic of 1703 was very brutal. The next epidemic began in 1710 on the localities of Poltava. According to the chronicle, only the St. Michael's Monastery on Starokyivska Hill remained inaccessible to it due to its isolation from the city. Then the plague reached Chernihiv, Nizhyn and other cities of Ukraine. A large epidemic, which broke out in 1738-1739, spread along the Dnieper and covered Zaporozhian Sich. In Slobidska Ukraine, in particular in Kharkiv, half of the population died from it. Only two old monks survived in the Sviatogorsk monastery. In the summer of 1749, an epidemic began in the Crimea, which spread to Zaporozhian Sich again. This time the inhabitants of the Samara monastery were especially affected.

The huge damage of Russian economy caused by the plague epidemic forced the state authorities to take certain measures against its spread. The decree of July 1710 ordered to put outposts on the roads from Cherkasy cities, as well as in all "Greater Russian cities bordering with Little Russia", and not to pass any inhabitants from Little Russia to Great Russia [8]. The organization of border outposts was a temporary measure, as they were established only in cases of an epidemic. Gradually institutions for the constant monitoring of outbreaks of plague and the implementation of precautionary measures against it began to be established. According to the order of Senate, the organization of quarantine buildings at the border customs in the Kyiv province was began [9]. In total there were six quarantines in Ukraine, the first of which was built in 1740 in Vasylkiv. Its subdivisions in Dobryanka, Pereyaslav, Cherkasy, Kremenchuk, Perevolochnia, Bakhmut, Izium, and Luhansk were subordinated to the Vasylkiv Quarantine. Starting from March 1764, Doctor of Medicine I.A. Poletika (1722-1783) took up the post of chief border doctor and headed a very important for that time quarantine service during twenty years. Until the end of his life, he continued to work in Vasylkiv, taking an active part in the work of the Kyiv Quarantine Hospital at the same time.

The most terrible of the epidemics that affected the lands of Ukraine in the XVIII century was the $10^{\text {th }}$ one. In 1770 , during the Russo-Turkish War, a deadly plague from Moldavia and Wallachia spread to Transylvania and Poland, and then to Ukraine. Here it reached Khotyn, in May it spread to the Right Bank of Ukraine - to Starokostiantyniv, Husiatyn and Zalishchyky; in July - to Mezhybizh and Zhovkva (25 km from Lviv), in early August - to Berdychiv. On August 2 Kyiv magistrate announced about the first plague victims in the city. To eliminate the epidemic, a team of doctors was organized, led by graduates of the Kyiv-Mohyla Academy, border quarantine doctor I.A. Poletika and the chief physician of the Kyiv hospital S.M. Mitrofanov (died of the plague in 1772). The plague also took the life of Dr. K.I. Shchepin (1728-1770). The boy, who was less than 15 years old, came to Kyiv from the Vyatka province almost on foot, like Lomonosov, and became the first student of the Kyiv-Mohyla Academy who dedicated himself to medicine. He joined the fight against the plague epidemic in Kyiv voluntarily.

Another graduate of Kyiv-Mohyla Academy, D.S. Samoilovich (1742-1805) took the path of struggle with a terrible disease too. Passing through Kyiv he actively joined his colleagues, who were gathering in Pechersk, in the house of I.A. Poletika discussing the issues of patients isolation, disinfection of their things and accommodations [10]. Three parts of Kyiv - Podil, Stare Misto and Pechersk - were surrounded by guards and isolated from each other. Cyril Monastery was turned into an infirmary, and quarantine was opened on Trukhanov Island. However, as later noted by D.S. Samoilovich, at that time, i.e. before the epidemic of 1770 , there were neither observations of the plague, nor proper experience in combating it [11].

About centuries-old attempts of mankind to understand the real causes of the plague I.I. Mechnikov wrote the following: "There was a time when the plague was attributed to heavenly wrath ... then people were killed on the altars - and supposed to reduce mortality from the epidemic by this. Later, leaving the branch of the supernatural, they began to look for the source of the plague in the influences outgoing from celestial bodies ... finally, even later they tried to find the cause of the plague on our planet, seeing it in earthquakes and floods"[1]. Doctors of the pre-bacterial period, who were divided into contagonists and miasmatists in their views on the development of infectious diseases, also moved not far from the outdated views. Contagonists believed that the terrible disease occurs through contact of a healthy 
person with the patient - directly or through his things. They recommended preventing these contacts, which, although it prevents the spread of the disease, does not solve the problem of its etiology. Proponents of the miasmatic theory were of the opinion about spread of infection through spoiled air, which contains miasm - the product of evaporation of rotting bodies; their advice to prevent the plague was not only baseless but also harmful. To improve air circulation, they proposed cutting down all the trees and bushes in and around the city or firing intense cannons and the continuous ringing of church bells to disperse the miasmatic air. Many years later Samoilovich, who from the very beginning defended the contagious theory and already had extensive experience in combating the plague, wrote that in the event of an epidemic it is necessary to "raise people's courage by showing them with simple examples that such a cruel disease can be fought and that there are ways that prevent its spread" [11]. After Kyiv, he visited Chernihiv and Nizhyn, where he recommended rational methods of combating the plague: timely detection of the disease, immediate isolation of patients and disinfection of their things with fumigation powder, proposed by a graduate of the Kyiv-Mohyla Academy K.Y. Jagielski (17361774). Arriving to Moscow for further appointment, Samoilovich joined the Commission for the treatment and prevention of plague established on October 12, 1771, and also offered his candidacy as a doctor of the plague hospital. Another native of Ukraine, O.F. Shafonsky (1710-1811) who studied in Kyiv-Mohyla Academy at the same time as Samoilovych took an active part in the work of the Commission. It was he who established the true nature of the Moscow epidemic and contributed to the organization of effective public health measures [11].

From 1776 to 1783 D.S. Samoilovich was abroad, where he defended his doctoral dissertation. After returning to his homeland, he led the organization of anti-plague measures in Crimea, Kherson region, Kremenchuk, Katerynoslav, and Odessa. While still alive, he gained the fame of a prominent physician and epidemiologist. He was the first in the Russian Empire to identify ways of plague transmitting, showed possible ways to successfully prevent and spread it. It was he whom meant D.K. Zabolotny, noting that "the expressions used and supported by the epidemiologist of the XVII century long before the discovery of the plague bacillus, ... show how close to the truth were ideas of doctors at that time" [12].
In the XIX century, the spreads of plague in Ukraine did not stop. It visited Odessa five times: in 1812-1813, in 1821, 1829, 1831 and 1837. The last time it was brought by a sick sailor from a ship that came from Constantinople. From there the disease spread to Podillya and Volyn and had such hard impact on the economy of these provinces that their population was exempt from taxes for three years [8]. A significant role in its liquidation was played by a native of Volyn E.S. Andreievsky (1809-1872), who after graduating from the University of Berlin and defending his doctoral dissertation in 1883 came to Odessa, where he held the position of divisional physician. Under his leadership, an effective scheme of anti-epidemic measures was drawn up and put into effect. He left a detailed description of this epidemic in a work that can be considered one of the best descriptions of the plague of the XIX century [13].

However, when the epidemiology of the plague attracted the attention of G.M. Minkh at the end of the XIX century (1836-1896), information about its origin, treatment and spread were far from complete. Expeditions to the places of outbreaks of plague epidemics, accompanied by many difficulties and a serious threat to his health and even life, took places mostly in Kyiv, the last and most fruitful period of his activity [14]. The fundamental work of the scientist, dedicated to the plague, was published only after the death of Minch by his student V.F. Nedelsky at the expense of the widow, Lyudmila Illivna Minkh. This paper contains important information on the peculiarities of the pathogenesis of plague, provides recommendations for limiting of its spread and a list of treatment methods tested by the author [15].

In 1895, after resignation of G.M. Minkh, his position as a professor of pathological anatomy at the University of Kyiv was taken over by a graduate of Kharkiv University V.K. Vysokovych (1854-1912), who also played a significant role in the fight against the plague. When the plague in Bombay in 1896 began to threaten countries around the world, expeditions led by bacteriologists from England, Italy, France, Germany, Russia, and Austria-Hungary were sent to India to prevent the spread of the plague. The French mission was headed by A. Jersen (1863-1943), who in 1894 discovered the causative agent of the plague. At the head of the Russian group was V.K. Vysokovych, who chose as assistants his Kyiv's colleagues such as D.K. Zabolotny from his department and doctor E.A. Redrova from Bacteriological Institute. On February 10, 1897, at the Kyiv railway station a 
solemn farewell of the expedition took place. This researcher group arrived in Bombay two weeks later. There our researchers performed epidemiological and clinical observations, examined the blood and secretions of patients, tested the effects of serum on patients, and performed experiments on animals to determine the course of infection and the properties of their immunity [16]. According to D.K. Zabolotny, participation in an expedition to India in 1897 gave him the opportunity to "test his possibilities as a researcher, see how the world's scientists work." Upon his return, he was enrolled as a specialist in the anti-plague laboratory of the Imperial Institute of Epidemic Diseases, which was opened in 1890 in St. Petersburg.

In August 1897, speaking at the XII International Congress of Physicians in Moscow, I.I. Mechnikov stated the priority of V.K. Vysokovych in establishing the therapeutic effect of anti-plague serum: "According to Professor Vysokovych's report, the serum can not only protect monkeys from plague, but also cure them. These results are very significant, because they are obtained in the conditions of an accurate experiment" [17]. Experience in the fight against plague, acquired by V.K. Vysokovych in India, was useful to him in preventing plague epidemics in the Russian Empire: in Kolobovka (1889), Vladimirovka (1889), Batumi (1889), Odessa $(1901,1902,1910)$ [18].

At the invitation of the Indian authorities, V.A. Khavkin (1860-1930), a native of Odessa, a graduate of Novorossiysk University, a student of I.I. Mechnikov in Odessa and employee in Paris, arrived to Bombay. Within three months, he developed the world's first plague vaccine, called Khavkin's lymphoma, and tested it first on himself, then on volunteers, and only then began vaccinating of patients. From 1897 to the 40's of XX century, his vaccine remained the best measure in the fight against plague.

A significant contribution to the epidemiology and epizootology of plague was made by M.F. Gamaliia (1859-1949). Particular values for epidemiological practice were his works carried out during the Odessa epidemic of 1901-1902. Together with the zoologist O.O. Browner he found two breeds of rodents on ships sailing to Odessa and on the streets of the city: black ship rats and brown land rats. From ship rats fleas transmitted the infection to the local rodent population and to humans. Gamaliia proposed the term "disinsection", which means the destruction of ectoparasite insects carriers of infection in the human environment, in contrast to disinfection - the destruction of microbes. He also developed a set of disinsectizers: mechanical (cleaning), physical (exposure to dry hot air, boiling water, hot steam, fire) and chemical (sulfur dioxide, kerosene, green soap solution) [19]. Deratization, the control of rodents that carried the disease, was also complex. According to the plan of Gamaliia special deratization detachments were created, which used hunting, traps, poisoning, burning and biological deratization against rodents at the suggestion of V.K. Vysokovych, namely, the artificial spread of the culture of rat typhus [20]. Pest control, performed first time in Russia, was presented in a special manual [21]. Unfortunately, the rational methods proposed by M.F. Gamaliia and V.K. Vysokovych in 1901-1902, were not used during the next plague epidemic in Odessa in 1910 due to the negligent attitude of the city administration, and therefore the existing success in combating the disease could not be achieved that time [22]. Even participation of D.K. Zabolotny who was already a well-known plague fighter at that time, did not help in the preparation of antiplague measures.

As far back in 1898, in order to eliminate local focuses of plague, D.K. Zabolotny went to Mongolia and China at the head of the expedition, which included a $5^{\text {th }}$ year student of St. Vladimir Kyiv University, native of Katerynoslav, V.A. Taranukhin (1834-1920). He already got experience of the fight against the plague there. In the same year Taranukhin was appointed an intern at the "Special Laboratory for the Production of Anti-Bubonic Plague Drugs" at the infamous Kronstadt Plague Fort [23]. In that place he prepared a dissertation on experimental research. Meanwhile, D.K. Zabolotny continued to fight the plague in various countries around the world. Thus, in 1899 he studied its course in Persia, Arabia and Mesopotamia, in 1900 - in the steppes of Kyrgyzstan and the Volga region, in 1904 - in Scotland. The materials he collected helped to reveal various aspects of the epidemiology and spread of the disease, its causative agent was known and studied, but the question remained unclear: where does the causative agent of plague is located between outbreaks of an epidemic? The answer to this question was finally received by D.K. Zabolotny during an expedition to study the pneumonic plague epidemic of 1910-1911 in Manchuria [24]. The expedition included medical scientists, doctors who worked in Manchuria at that time and volunteers medical students. Among them was also a student of Novorossiysk University L.V. Gromashevsky 
(1887-1980), for whom the expedition became the first major epidemiological experience. Staying in Harbin, he treated sick Chinese, disinfected their homes, carried out various anti-epidemic measures, removed corpses, a lot of which were in the city and other settlements, and prevented the epidemic spread to the Russian Empire. The risk for life was very high -28 people, three quarters of the personnel of the anti-plague expedition led by Professor Zabolotny, died of plague.

The death of researchers who selflessly competed with a deadly disease was not the first time, but finally an important step was taken to overcome it. Zabolotny's hypothesis about the existence in nature of permanent plague focus was confirmed experimentally, the role of tarbagans and ground squirrels in its distribution was revealed. Plague bacillus extracted from sick or dead rodents found in the steppe, after its introduction to laboratory animals, caused their death. This discovery was of great importance for the development of the whole doctrine of the plague: it explained the causes of the endemic essence of a terrible disease in nature [25].

Today we have all reasons to be proud that many pioneers of epidemiology were researchers from Ukraine. Our compatriots have come a long way - from Samoilovich to Zabolotny, from the XVIII to the XX century, until the basic laws of the plague, its spread and course have been established, and reliable methods of its prevention and control have been proposed. The peculiarities of the development of its causative agent were clarified, the natural centers of its existence were identified, its carriers during epizootics were found, the ways of transmitting the causative agent of plague to humans through animals and insects were discovered, and a vaccine was proposed.

Since the 30's in the XX century, the incidence of plague was limited, and mortality from it decreased significantly. But the severe disease has not completely left our planet: almost every year it occurs in 8 countries around the world: China, Mongolia, Vietnam, Congo, Tanzania, Madagascar, Peru and the United States. Ukraine is not included to this sad list, and the new generation of our doctors is familiar with the plague only from literary sources. Information about it disappears from the standard program and textbooks for medical students every year. However, the memory of the successes of the brave "plague hunters" is of imperishable value, and not only to the medical community. The history of medicine, an important component of which is the history of epidemiology, is one of the sections of the general history of culture, which carries a significant methodological load. The experience that mankind has gained from the history of the fight against plague can help to learn the general epidemiological patterns, to find out the causes of infectious diseases of today, and in the development of rational anti-epidemic measures.

\section{ВНЕСОК УКРАЇНСЫКИХ ВЧЕНИХ У БОРОТЬБУ З ЧУМОЮ}

\author{
В.М. Гамалія, С.П. Руда, Г.В. Забуга
}

Державна установа «Інститут досліджень науково-технічного потенціалу та історії науки ім. Г.М. Доброва НАН України»,

бульв. Т. Шевченка, 60, Київ, 01032, Украӥна

\section{Резюме}

Пропонується огляд історії боротьби українських вчених з однією з найжорстокіших інфекційних хвороб людства. Відмічено, що епідемії чуми переслідували людство протягом багатьох століть. Тривалий час пандемії так званої «чорної смерті» спалахували в різних куточках планети. Показано, як в межах боротьби з чумною інфекцією в Російській Імперії було організовано низку заходів проти її занесення: організація прикордонних застав, влаштування карантинних госпіталів тощо. Розглянуто шляхи пошуку причин виникнення чуми низкою вчених, зокрема випускниками Києво-Могилянської академії, лікарями І.А. Полетикою, Д.С. Самойловичем, К.Й. Ягельським, О.Ф. Шафонським. Описано формування протичумної системи в Російській імперії, починаючи з кінця XIX ст. Показана діяльність протичумної лабораторії, організованої за ініціативою академіка Д.К. Заболотного у 1880 р. в Петербурзі. Показано внесок лікарів Г.М. Мінха, В.К. Високовича та М.Ф. Гамалії у розкриття особливостей патогенезу чуми. Зазначено, що лише на початку XX століття лабораторії, очолювані Д.К. Заболотним та I.I. Мечниковим, отримали вагомі результати стосовно шляхів розповсюдження цієї небезпечної інфекції. Доведено, що лише самовіддана праця плеяди науковців дозволила не тільки знизити, але й побороти захворюваність чумою. Зазначається, що перше об'єктивне підтвердження того факту, що збудник чуми може передаватися від гризунів до людини, було отримано в 1912 р. Значну увагу приділено дослідженням чумної інфекції Д.К. Заболотним під час експедицій до країн, де виника- 
ли епідемії. Підкреслено роль українських вчених у встановленні основних закономірностей виникнення чуми, а також розробці методів запобігання цій інфекційній хворобі.

1. Mechnikov II. [Scientific advances in the study of plague and in the fight against it]. Russkij arhiv patologii. 1897; 4:133-50. Russian.

2. Fukidid. [History]. Moskva: Ladomir; 1999. 736 p. Russian.

3. Bokkachcho Dz. [The Decameron]. Moskva: Izdvo hudozhestv. 1-ry; 1970. 793 p. Russian.

4. Defoe D. Journal of Plague Year: being observations or memorials of the most remarkable occurrences, as well public as private, which happened in London during the last great visitation in 1665 . Written by a Citizen who continued all the while in London. Never made public before. London; New York. 1911. 303 p.

5. [Novgorod First Chronicle. Berlin List]. SPb.: Izd-vo SPb. universiteta. Pisjmennye pamjatniki istorii i kultury drevnej Rossii v sobranijah zarubezhnyh arhivov i bibliotek. 2011. 464 p. Russian.

6. [Chernigov Chronicle/South Russian Chronicles, discovered and published by N. Belozersky]. Kiev. 1856; 1:11-44. Russian.

7. Verkhratskyi SA. [History of medicine]. Vyd. 3-je. Kyiv: Vyshcha shkola; 1983. 384 p. Ukrainian.

8. Borodii MK. [To the history of plague control in Ukraine in the XVIII century]. Ukrainskyi istorychnyi zhurnal. 1984; 5:82-90. Ukrainian.

9. Vasiliev KG, Lapushenko OV, Gozhenko AI. [Plague and border quarantines. Historical and epidemiological sketch]. Odessa: ChP «Fotosintetika»; 2004. 196 p. Russian.

10. Borodii MK. [Danylo Samiilovych Samoilovych]. Kyiv: Naukova dumka; 1987. 151 p. Ukrainian.

11. Samoilovich DS. [Discourse about the plague that devastated the Russian Empire in 1771 and especially in the capital city of Moscow]. Izbr. proizv. Vyp. 2. Moskva: Izd-vo AMN SSSR; 1952. p. 7-248. Russian.
Ключові слова: чума, вакцинація, епідеміологія, протичумна сироватка, епізоотія, ендемічність.

12. Zabolotny D. [Plague (Pestis bubonica): Epidemiology, pathogenesis, prevention]. Sb. rabot po chume. SPb. 1907; 1:1-94. Russian.

13. Andreievskii ES. [About the plague that befell Odessa in 1837: Historical view of the course of the infection and medical observations over it]. Odessa: Gor. tip.; 1838; 4:137. Russian.

14. Ruda SP. [Grigorii Nikolaievich Minkh. 18361896]. Kiev: GP «Informatsionno-analiticheskoie agentstvo»; 2011. 231 p. Russian.

15. Minkh GN. [Plague in Russia. Part 1. (Posthumous edition)]. Kiev. 1898. 354 p. Russian.

16. Ruda SP. [Vladimir Konstantinovich Vysokovich, 1854-1912]. Moskva: Nauka (Nauchno-biograficheskaia literatura); 2004. 175 p. Russian.

17. Ruda SP. [V.K. Vysokovych - scientist, teacher, man. Life, dedicated to people. To the 160th anniversary of the birth of Vladimir Konstantinovich Vysokovich]. Kyiv: Nacionalna naukova medychna biblioteka Ukrainy (Tovarystvo kyivskykh likariv v osobakh); 2014. p. 9-11. Ukrainian.

18. Vysokovich VK. [Plague (Pestis orientalis)]. Kiev: Tipografiia MM Fiha; 1901. 31 p. Russian.

19. Ruda SP. [Essays on the history of microbiology in Ukraine (late XIX - early XX century)]. Kyiv: IVC Derzhkomstatu Ukrajiny; 2000. 262 p. Ukrainian.

20. Gamaliia VM. [To the 150th anniversary of the birth of MF Gamaliia (1859-1949)]. Nauka ta naukoznavstvo. 2009; 2:66-75. Ukrainian.

21. Belilovskii VA, Gamaleia NF. [Plague in Odessa]. Odessa; 1903. 176 p. Russian.

22. Vysokovich VK. [Plague in Odessa in 1910. Epidemiology, pathology, clinic, bacteriology and measures]. pod. red. SN Malinovskogo, DK Zabolotnogo, PN Bulatova. SPb; 1912. 156 p. Russian.

23. Blohina NN. [On the history of the anti-plague service in Russia at the beginning of the 20th 
century]. Epidemiologiia i infekcionnye bolezni. 2012; 1:56-61. Russian.

24. Bilai VI. [Danil Kirillovich Zabolotny]. Kiev: Naukova dumka; 1987. 128 p. Russian.
25. Ruda SP. [Works of epidemiologists of Ukraine XVIII - XIX centuries in light of the threat of bacteriological warfare]. Narysy $\mathrm{z}$ istoriji pryrodoznavstva i tekhniky. 2005; 45:74-80. Ukrainian.

Received 19.11.2020 